\title{
Jurist-Diction
}

Volume 3 No. 5, September 2020

\section{Pertanggungjawaban Bank Dalam Perkara Tindak Pidana Pencucian Uang yang Tidak Menjalankan Prinsip Kehati-Hatian}

\author{
Istiqomah \\ istiistiqomah013@gmail.com \\ Universitas Airlangga
}

\begin{abstract}
How to cite: Istiqomah,

'Pertanggungjawaban Bank Dalam Perkara Tindak Pidana Pencucian Uang yang Tidak Menjalankan Prinsip KehatiHatian' (2020) Vol. 3 No. 5 Jurist-Diction.

Histori artikel: Submit 20 Mei 2020; Diterima 14 Agustus 2020; Diterbitkan 1 September 2020

DOI:

10.20473/jd.v3i5.21980
\end{abstract}

\begin{abstract}
Abstrak
Tindak Pidana Pencucian Uang yang dikenal dengan istilah money laundering merupakan proses dimana aset-aset pelaku terutama asset tunai yang diperoleh dari suatu tindak pidana dimanipulasikan sedemikian rupa sehingga aset tersebut seolah-olah berasal dari sumber yang sah. Bank sebagai lembaga penyedia jasa keuangan menjadi incaran dan sarana untuk melakukan tindak kejahatan termasuk tindak pidana pencucian uang. Adanya prinsip kehati-hatian bank salah satunya bertujuan untuk mencegah bank menjadi media tindak pidana pencucian uang, turunan dari prinsip kehati-hatian bank adalah prinsip mengenal nasabah yang telah berkembang menjadi prinsip customer due dilligence (CDD) dan enhanced due dilligence (EDD) wajib diterapkan oleh bank, kegiatan berupa identifikasi calon nasabah dan memantau karakteristik transaksi setiap nasabah, serta melaporkan apabila ada transaksi mencurigakan sesuai dengan peraturan perundang-undangan. tindakan bank yang tidak menjalankan prinsip tersebut akan dikenakan hukuman sebagaimana yang diatur dalam peraturan perundang-undangan mengenai prinsip mengenal nasabah. Maka seharusnya bank bertanggungjawab ketika tidak melaksanakan prinsip kehati-hatian bank berkaitan dengan upaya pencegahan tindak pidana pencucian uang.

Kata Kunci: Pencucian Uang; Customer Due Diligence; Enhanced Due Diligence; Pertanggungjawaban Korporasi.
\end{abstract}

\section{Pendahuluan}

Dewasa ini perkembangan kehidupan masyarakat yang semakin kompleks telah menumbuhkan berbagai bentuk kejahatan dan semakin sulit untuk merumuskan norma hukum dalam penanggulangannya. Tindak pidana korupsi seakan menjadi sebuah trend dilingkungan pemerintahan maupun dilingkungan swasta, tak sedikit pejabat yang melakukan tindak pidana korupsi secara jelas dan nyata merugikan keuangan negara. Korupsi tidak hanya dilakukan oleh pejabat dikalangan pusat tapi kian marak dari waktu ke waktu di kalangan pejabat daerah dalam lingkup provinsi maupun kabupaten/kota. 
Tidak hanya korupsi, Tindak Pidana Pencucian Uang (TPPU) menjadi problem yang kini beramai-ramai dilakukan oleh para pejabat di negara kita meskipun secara tegas telah diatur dalam Undang-Undang Nomor 8 Tahun 2010 tentang Pencegahan dan Pemberantasan Tindak Pidana Pencucian Uang (selanjutnya disebut Undang-Undang PP TPPU). Kejahatan pencucian uang atau yang dikenal dengan istilah money laundering adalah suatu perbuatan kriminal yang berkaitan dengan latar belakang perolehan uang yang sifatnya gelap dan kotor, kemudian dikelola sedemikian rupa dengan aktivitas tertentu misalnya membentuk usaha, dengan transaksi keuangan seperti mentransfer atau mengkonversikannya ke bank guna menyembunyikan atau menyamarkan asal-usul uang atau harta kekayaan yang merupakan hasil tindak pidana lain. Setelah melalui saluran yang legal tersebut maka secara yuridis uang tersebut seolah-olah merupakan uang yang berasal dari sumber dan kegiatan yang legal, sehingga sulit untuk menelusuri dan melacak sumber asal uang tersebut. Dengan demikian pelaku dapat dengan leluasa memanfaatkan harta kekayaan tersebut dengan meminimalisir kecurigaan.

Pada proses pencucian uang (money laundering) terdapat 3 (tiga) tahap yakni placement, layering, dan integration. Salah satu kegiatan placement (penempatan) adalah menempatkan dana hasil dari suatu kegiatan tindak pidana ke dalam sistem keuangan, biasanya dilakukan dengan memecah uang ke dalam jumlah yang lebih kecil kemudian di tempatkan di beberapa akun rekening di bank guna menyamarkan dana agar tidak mudah dilacak atau disebut dengan smurfing. Tahap ini adalah tahap yang paling sederhana dengan mengubah uang yang dihasilkan dari suatu kegiatan tindak pidana ke dalam bentuk yang tidak menimbulkan kecurigaan dan pada akhirnya dapat masuk ke dalam jaringan sistem keuangan. ${ }^{1}$ Upaya menempatkan dana hasil suatu kegiatan tindak pidana kedalam sistem keuangan berupa penempatan dana atau harta hasil tindak kejahatan atau perbuatan melawan hukum ke dalam saham-saham, real estate, deposito bank, mengkonversi ke mata uang lainnya, atau melakukan transfer ke dalam valuta asing untuk sementara 
waktu. ${ }^{2}$ Tahap ini merupakan fase penempatan uang hasil suatu aktivitas kejahatan, misalnya dengan pemecahan sejumlah uang tunai besar menjadi jumlah kecil untuk ditempatkan dalam sistem keuangan bank, menggunakan rekening simpanan bank, atau digunakan untuk membeli sejumlah instrumen keuangan yang akan ditagihkan kemudian di depositokan di rekening bank yang berada di lokasi yang lain.

Ada beberapa kegiatan dalam Placement, diantaranya, menempatkan uang dalam sistem perbankan; memecah-mecah transaksi dalam jumlah kecil; menyelundupkan uang atau harta kekayaan hasul tindak pidana ke negara lain; melakukan penempatan secara elektronik; melakukan konversi harta hasil tindak pidana; menggunakan beberapa pihak dalam melakukan transaksi; melakukan konversi harta hasil tindak pidana. ${ }^{3}$

Berkaitan dengan tahap-tahap dalam pencucian uang, ada satu kasus yang menarik untuk dibahas yakni kasus mantan bupati Bangkalan Jawa Timur Fuad Amin yang menjabat selama 10 (sepuluh) tahun, pada periode 2003-2008, periode 2008-2013, dan selaku mantan Ketua Dewan Perwakilan Rakyat Daerah (DPRD) Kabupaten Bangkalan Jawa Timur. Fuad Amin dijatuhi pidana penjara selama 13 (tiga belas) tahun penjara dan denda sebesar Rp 5 milyar oleh Mahkamah Agung.

Majelis Mahkamah Agung menilai bahwa Fuad Amin terbukti secara sah dan meyakinkan melakukan tindak pidana pencucian uang. Hal tersebut karena Fuad terbukti menempatkan, mentransferkan, membelanjakan, membayarkan, menukarkan dengan mata uang harta kekayaan yang diketahui atau patut diduga bersumber dari hasil tindak pidana korupsi. dengan maksud menyembunyikan atau menyamarkan asal-usul harta kekayaanya. Pertimbangan lainnya, majelis juga menilai bahwa harta yang dimiliki oleh Fuad Amin tidak dapat dibuktikan jika berasal dari hasil usaha yang legal atau sah, dengan begitu maka harta tersebut harus dirampas untuk negara.

\footnotetext{
2 Ruslan Renggong, Hukum Pidana Khusus (Memahami Delik-delik di Luar KUHP), (Kencana 2016).[94].

3 Pusat Pelaporan dan Analisis Transaksi Keuangan (PPATK) Modul E-Learning 1, "Pengenalan Anti Pencucian Uang dan Pendanaan Terorisme", [3]. <http://elearning.ppatk.go.id/pluginfile.php/269/mod_page/content/5/Mod\%201\%20-\%20Bag\%202\%20-\%20Tipologi\%20Pencucian\%20Uang.pdf $>$ accessed 13 November 2019.
} 
Kronologi atas dakwaan tindak pidana pencucian uang pada Fuad Amin jika melihat putusan pengadilan, data-data yang dipaparkan membuat tercengang melihat terjadinya tindak pidana korupsi dan pencucian uang yang besar-besaran dan sistematis yang dilakukan Fuad Amin. Fuad yang terbukti melakukan kejatahan tindak pidana pencucian uang dengan cara mentransfer ke rekeningnya yang kepemilikannya diatasnamakan beberapa teman dekatnya yang dengan demikian rekening rekening bank tersebut tidak terdaftar dalam LHKPN (Laporan Harta Kekayaan Penyelenggara Negara). Rekening bank atas nama dirinya pun ternyata berbeda-beda, menurut data yang dipaparkan, ada yang terdaftar dengan nama FUAD AMIN, RKH.FUAD AMIN, H. FUAD AMIN, dan KH. FUAD AMIN. Tak hanya menggunakan nama yang berbeda-beda di beberapa bank yang berbedabeda di Kabupaten Bangkalan Jawa Timur dan wilayah lain, Fuad juga membuat rekening atas nama orang lain yang termasuk anak, keluarga, dan orang lain yang dipinjam KTP nya untuk pembukaan rekening dengan cara memanggil orang bank untuk datang kerumah Fuad untuk menandatangani aplikasi pembukaan rekening dan penerbitan ATM, kemudian buku rekening dan ATM tersebut dikuasai oleh Fuad Amin. ${ }^{4}$

Kasus tersebut di atas yang menjadi menarik untuk diteliti berkaitan dengan penerapan prinsip kehati-hatian bank yang berkaitan dengan upaya pencegahan tindak pidana pencucian uang yang seharusnya diterapkan oleh bank. Dalam kasus tersebut, Fuad Amin dapat menyimpan dan menempatkan uang hasil korupsinya atas namanya sendiri dengan identitas yang berbeda-beda di beberapa bank yang ada di beberapa wilayah. Prinsip kehati-hatian bank sebagai upaya pencegahan tindak pidana pencucian uang yang menjadikan bank sebagai media atau sarana tindak pidana tersebut adalah dengan menerapkan prinsip bank yakni prisnsip mengenal nasabah. Sebagaimana yang telah diatur dalam Peraturan Bank Indonesia (PBI) No.3/10/PBI/2001 tentang Penerapan Prinsip Mengenal Nasabah (Know Your Customer) sebagai pengaturan pertama dari prinsip mengenal nasabah,

4 Putusan mahkamah Agung, nomor 980 K/Pid.Sus/2016 tahun 2016, tentang Permohonan kasasi, Perkara H.Fuad Amin, 29 Juni 2016. 
dan telah diubah dengan PBI No.5/21/PBI/2003, yang dimaksud dengan prinsip mengenal nasabah adalah prinsip yang diterapkan bank untuk mengetahui identitas nasabah, memantau kegiatan transaksi nasabah termasuk pelaporan transaksi yang mencurigakan, nasabah dalam pengertian disini adalah nasabah yang menggunakan jasa bank.

Dalam perkembangannya prinsip mengenal nasabah ini mengalami penyempurnaan dengan dikeluarkannya PBI Nomor 11/28/PBI/2009 tentang Penerapan Program Anti Pencucian Uang dan Pencegahan Pendanaan Terorisme Bagi Bank Umum, yang menyebutkan bahwa ketentuan tentang penerapan prinsip mengenal nasabah (know your customer) perlu disempurnakan dengan adanya prinsip Customer Due Dilligence (CDD) dan Enhanced Due Dilligence (EDD).

Tujuan diterapkannya prinsip mengenal nasabah adalah untuk mengenal profil dan karakter transaksi nasabah, sehingga sejak dini bank dapat mengidentifikasi transaksi yang diduga mencurigakan tersebut. Prinsip mengenal nasabah bertujuan pula untuk meminimalisasi operational risk yakni risiko bank tidak dapat melakukan kegiatan operasionalnya secara normal karena tidak berfungsinya proses operasi pada bank. Legal risk yakni risiko yang disebabkan adanya kelemahan aspek yuridis, concentration risk yakni risiko yang terjadi karena bank menerima dana dari pihak ketiga dalam jumlah besar yang terkonsentrasi pada beberapa nasabah, dan reputational risk yakni risiko disebabkan oleh adanya publikasi negatif terkait dengan kegiatan usaha bank. ${ }^{5}$

Prinsip mengenal nasabah dianggap perlu diterapkan oleh bank pada seluruh nasabah apapun jenisnya dan dalam transaksi apapun yang dilakukan nasabah dengan bank, wajib dilakukan identifikasi oleh bank berdasarkan pinsip mengenal nasabah. Dengan demikian, baik bank maupun nasabah sama-sama mengetahui aspek hukum berkaitan dengan hal yang dimaksud, dan pada akhirnya kedua belah pihak dapat memahami fungsi serta kewajiban masing-masing dalam bentransaksi. ${ }^{6}$

5 Nidyo Pramono, Bunga Rampai Hukum Bisnis Aktual (Cintra Aditya 2006).[218] .

6 Try Widyono, Aspek Hukum Operasional Transaksi Produk Perbankan di Indonesia (Ghia Indonesia Bogor 2006).[77]. 
Bicara soal pertanggungjawaban pidana didalam hukum pidana yang dikenal dalam istilah asing disebut criminal responsibility menjurus pada pemidanaan bagi pelaku, dengan maksud untuk menentukan apakah seseorang tersangka atau terdakwa dapat mempertanggungjawabkan atas suatu tindak pidana yang terjadi. Seseorang dipertanggungjawab pidanakan harus dilihat apakah tindakan, perbuatan, atau kegiatan individu itu sudah ada atau belum aturannya, ini yang disebut dengan asas legalitas, dan apakah telah memenuhi unsur-unsur yang telah ditentukan dalam peraturan perundang-undangan dan di atas umur tertentu dan mampu bertanggung jawab serta tidak adanya alasan pemaaf. Dengan kata lain pertanggungjawaban pidana adalah untuk menentukan apakah seseorang tersebut dipidana atau dibebaskan. ${ }^{7}$

Pertanggungjawaban pidana tidak hanya terbatas pada subjek hukum perseorangan atau dengan istilah yang kita kenal dengan naturlijk persoon namun telah menjangkau pada subjek hukum lain yakni badan hukum atau rechts person dalam hukum perdata, sedangkan dalam hukum pidana dikenal dengan istilah korporasi. ${ }^{8}$ Membahas masalah pertanggungjawaban korporasi yang tentu tidak bisa dilepaskan dari tindak pidana, pengaturan pertanggungjawaban korporasi salah satunya ada di dalam Undang-Undang PP TPPU dan Undang-Undang Perbankan. Sama halnya dengan pertanggungjawaban pidana pada orang, korporasi juga dapat dimintakan pertanggungjawaban pidana sesuai dengan ketentuan pidana korporasi dalam undang-undang yang telah mengakui korporasi sebagai subjek hukum dan mengatur tentang korporasi. Tidak terbatas pada Undang-Undang PP TPPU atau Undang-Undang Perbankan saja, namun juga peraturan perundang-undang lainnya yang telah merumuskan bahwa korporasi dapat dimintakan pertanggungjawaban pidana ketika terbukti melakukan kesalahan.

Berdasarkan kasus Fuad Amin mantan bupati sekaligus mantan ketua DPRD Kabupaten Bangkalan Jawa Timur yang telah dipaparkan, menjadi menarik untuk diteliti adalah masalah prinsip kehati-hatian bank dan prinsip mengenal nasabah,

\footnotetext{
7 Didik Endro Purwoleksono, Hukum Pidana, Airlangga (University Press Surabaya 2014).[63].

8 Ruslan Renggong.Op Cit.[35].
} 
hubungannya dengan tindak pidana pencucian uang. Serta pertanggungjawaban bank yang terlibat dalam kejahatan pencucian uang, kedua masalah tersebut akan dirumuskan sebagai rumusan masalah.

\section{Rumusan Masalah}

Berdasarkan uraian latar belakang di atas, adapun masalah yang akan dibahas dalam penulisan ini adalah sebagai berikut :

1. Tindakan bank yang tidak menjalankan prinsip kehati-hatian berkaitan dengan upaya pencegahan tindak pidana pencucian uang.

2. Pertanggungjawaban bank yang tidak melaksanakan prinsip kehati-hatian bank berkaitan dengan upaya pencegahan tindak pidana pencucian uang.

\section{Prinsip Mengenal Nasabah}

Dalam menjalankan usahanya bank haruslah menerapkan prinsip-prinsip perbankan. Prinsip penting yang harus diterapkan bank adalah penerapan prinsip kehati-hatian yang dikenal dengan prudential banking. Prinsip ini merupakan suatu asas yang menyatakan bahwa bank dalam menjalankan fungsi dan kegiatan usahanya wajib bersikap hati-hati (prudent) untuk melindungi dana masyarakat yang dipercayakan pada bank. ${ }^{9}$ Hal tersebut dijelaskan dalam Pasal 2 UndangUndang Nomor 10 Tahun 1998 tentang perubahan atas Undang-Undang Nomor 7 Tahun 1992 tentang Perbankan, bahwa perbankan Indonesia dalam melakukan usahanya berasaskan demokrasi dengan menggunakan prinsip kehati-hatian. Prinsip kehati-hatian ini bertujuan agar bank selalu dalam keadaan sehat dan baik dalam menjalankan usahanya, serta mematuhi ketentuan dan norma hukum yang berlalu di dunia perbankan. ${ }^{10}$ Selain itu untuk mempertahankan eksistensinya dalam masyarakat dan menjaga tingkat kepercayaan masyarakat, khususnya para nasabah

\footnotetext{
${ }^{9}$ Lukmanul Hakim dan Eka Travilta Oktaria, 'Prinsip Kehati-hatian Pada Lembaga Perbankan Dalam Pemberian Kredit' (2018) 9 Jurnal Keadilan Progresif.[168].

${ }^{10}$ Detisa Monica Podung, 'Kredit Macet dan Penerapan Prinsip Kehati-Hatian Dalam Perbankan' ( 2016) 5 Jurnal Lex Crimen. [50].
} 
yang telah maupun akan menyimpan dananya pada bank, atau yang menggunakan jasa-jasa bank lainnya.

Turunan dari pada prinsip kehati-hatian adalah prinsip mengenal nasabah. Pengaturan prinsip mengenal nasabah secara umum terdapat pada Peraturan Bank Indonesia (PBI) mengenai penerapan prinsip mengenal nasabah. Prinsip ini untuk pertama kali diatur dalam PBI Nomor 3/10/PBI/2001 tentang penerapan prinsip mengenal nasabah (know your customer). PBI ini memberikan definisi prinsip mengenal nasabah adalah prinsip yang wajib diterapkan pada bank untuk mengetahui identitas nasabah, memantau segala kegiatan transaksi nasabah termasuk melakukan pelaporan transaksi yang mencurigakan. Prinsip mengenal nasabah adalah prinsip yang wajib diterapkan oleh bank untuk mengetahui dan mencermati identitas calon nasabahnya. Selain itu juga melakukan pemantauan kegiatan transaksi yang dilakukan oleh nasabah, termasuk melakukan pelaporan apabila terdapat transaksi yang mencurigakan. ${ }^{11}$

Dengan adanya identifikasi nasabah oleh bank mengenai identitas diri dan buktinya, keuangan, serta motif transaksi, dan lain sebagainya yang diformulasikan dalam CIF (customer identification file) yakni file dari nasaabah yang di simpan bank. Maka baik bank maupun nasabah akan mengetahui aspek hukum berkaitan dengan hal dimaksud yang pada akhirnya kedua belah pihak memahami kewajiban, hak, dan fungsi masing-masing dalam melakukan transaksi. ${ }^{12}$ Dalam Surat Edaran Bank Indonesia (SEBI) Nomor 3/29/DPNP Tahun 2001 tentang Pedoman Standar Penerapan prinsip mengenal nasabah, dikemukakan bahwa prinsip mengenal nasabah ini merupakan salah satu upaya pencegahan terhadap penyalahgunaan sistem perbankan sebagai sarana kejahatan pencucian uang, baik dilakukan langsung maupun tidak langsung oleh pelaku kejahatan. Dengan menerapkan prinsip mengenal nasabah maka bank juga dapat meminimalisir risiko yang kemungkinan timbul yaitu operational risk, legal risk, concentration risk, dan reputational risk. ${ }^{13}$

\footnotetext{
11 Tri Sadini P.Usanti dan Abd.Shomad, Hukum Perbankan (Kencana 2016).[28].

12 ibid.[77-78].

13 Sentosa Sembiring, Hukum Perbankan Edisi Revisi (Mandar Maju 2012).[172].
} 


\section{Kebijakan penerimaan dan identifikasi nasabah}

Sebagai salah satu kewajiban dengan dikeluarkannya PBI Nomor 3/10/ PBI/2001 tentang Penerapan Prinsip Mengenal Nasabah (Know Your Customer) yang diikuti dengan dikeluarkannya PBI Nomor 5/21/PBI/2003 tentang Perubahan Kedua atas PBI Nomor 3/10/PBI/2001 adalah membuat suatu kebijakan dan prosedur penerapan prinsip mengenal nasabah. Atas dasar tersebut dibentuklah Pedoman Standar Penerapan Prinsip Mengenal Nasabah dalam Lampiran Surat Edaran Bank Indonesia Nomor 3/29/DPNP.

Pada prosedur penerimaan dan identifikasi nasabah khusunya pada penerimaan nasabah perorangan, dijelaskan bahwa nasabah diwajibkan untuk mengisi formulir standar yang telah ditetapkan oleh bank. Menurut ketentuan pada BAB III huruf a pedoman standar penerapan prinsip mengenal nasabah tersebut di atas, formulir tersebut sekurang-kurangnya memuat informasi berikut yakni:

1) Nama, tempat tanggal lahir, alamat serta kewarganegaraan yang dibuktikan dengan Kartu Tanda Penduduk (KTP), Surat Izin Mengemudi (SIM) atau paspor dan dilengkapi dengan informasi alamat tempat tinggal tetap apabila berbeda dengan yang tertera dalam dokumen. Khusus untuk warga Negara asing (WNA) selain psapor dibuktikan dengan Kartu Izin Menetap Sementara (KIMS/KITAS) atau Kartu Izin Tinggal Tetap (KITAP);

2) Alamat dan nomor telepon tempat bekerja yang dilengkapi dengan keterangan mengenai kegiatan usaha perusahaan/instansi tempat bekerja;

3) Keterangan mengenai pekerjaan/jabatan dan pengasilan calon nasabah, dalam hal calon nasabah tidak memiliki pekerjaan, maka data yang diperlukan adalah sumber pendapatannya;

4) Keterangan mengenai sumber dan tujuan penggunaan dana dari calon nasabah;

5) Spesimen tanda tangan.

Namun apabila diperlukan, bank dapat meminta informasi lainnya dari calon nasabah. Disebutkan juga dalam SEBI di atas khusus untuk calon nasabah yang melakukan pembukaan rekening melalui telepon, surat-menyurat atau electronic banking, maka petugas bank wajib melakukan pertemuan dengan calon nasabah sebelum pembukaan rekening tersebut disetujui. Kebijakan penerimaan dan identifikasi nasabah juga diatur dalam PBI Nomor 11/28/PBI/2009 tentang Penerapan Program Anti Pencucian Uang dan Pendanaan Terorisme Bagi Bank Umum. PBI ini adalah perkembangan pengaturan sekaligus penyempurnaan dari 
ketentuan tentang penerapan prinsip mengenal nasabah (know your customer). PBI Nomor 11/28/PBI/2009 mengganti ketentuan prinsip Know Your Customer (KYC) menjadi Customer Due Dilligence (CDD). Ketentuan PBI Nomor 11/28/PBI/2009 telah disempurnakan dengan PBI Nomor 14/27/PBI/2012.

Dijelaskan dalam PBI Nomor 14/27/PBI/2012, tentang Penerapan Program Anti Pencucian Uang dan Pencegahan Pendanaan Terorisme Bagi Bank Umum, dalam kebijakan pada saat melakukan hubungan usaha dengan calon nasabah bank dalam rangka melakukan hubungan usaha dengan nasabah, berlaku ketentuan sebagaimana yang dijelaskan pada Pasal 12, yakni:

a. Bank wajib untuk meminta informasi guna mengetahui profil dari calon nasabah;

b. Identitas calon nasabah harus dibuktikan dengan keberadaan dokumen pendukung;

c. Bank wajib untuk meneliti kebenaran dokumen pendukung identitas calon nasabah;

d. Bank dilarang untuk membuka dan memelihara rekening anonim atau tanpa nama serta rekening yang menggunakan nama fiktif atau palsu;

e. Bank wajib untuk melakukan pertemuan langsung secara tatap muka (face to face) dengan calon nasabah pada awal melakukan hubungan usaha dalam rangka guna meyakini kebenaran dari identitas calon nasabah.

Dalam PBI Nomor 14/27/PBI/2012 juga mewajibkan bank untuk mewaspadai transaksi atau hubungan usaha dengan nasabah yang berasal atau terkait dengan negara yang tergolong beresiko tinggi. Salah satu penerapan dari prinsip kehatihatian adalah bank diwajibkan untuk menerapkan prinsip mengenal nasabah pada saat pertama kali melakukan hubungan usaha dengan nasabah. Hal ini mengharuskan bank mengetahui dan mengenali calon nasabahnya.

Penerapan prinsip kehati-hatian dan prinsip mengenal nasabah oleh bank sangat penting untuk melindungi integritas, menjaga tingkat kepercayaan masyarakat terhadap bank dan reputasi sektor perbankan serta mencegah resiko bank sebagai alat kejahatan keuangan oleh pelaku tindak pidana. Penerapan prinsip mengenal nasabah ini menjadi penting sebagai gerbang pertama bank untuk mengantisipasi dan meminimalisir risiko atas transaksi yang mencurigakan dan akan merugikan bank. 


\section{Customer Due Dilligence (CDD)}

Dijelaskan pengertian CDD berdasarkan PBI PBI Nomor 14/27/PBI/2012 tentang Penerapan Program Anti Pencucian Uang dan Pencegahan Pendanaan Terorisme Bagi Bank Umum, adalah adalah kegiatan berupa identifikasi, verifikasi, dan pemantauan oleh bank guna memastikan bahwa transaksi nasabah sesuai dengan profil nasabah itu sendiri untuk mengurangi tingkat risiko terjadinya pencucian uang. Implementasi CDD dilakukan saat calon nasabah baik perorangan maupun badan hukum melakukan pembukaan rekening untuk pertama kali. Nantinya customer service (CS) meminta calon nasabah untuk mengisi formulir customer identification (CIF) yang dilampirkan dengan kartu identitas dari calon nasabah. ${ }^{14}$

Melihat ketentuan pada Pasal 10 PBI Nomor 14/27/PBI/2012, prosedur prinsip CDD wajib dilakukan bank pada saat:

a. Melakukan hubungan usaha dengan calon nasabah untuk pertama kali;

b. Melakukan hubungan usaha dengan Walk in Customer (WIC) yang dalam pengertiannya adalah pihak yang menggunakan jasa bank namun tidak memiliki rekening pada bank yang bersangkutan, tidak termasuk pihak yang mendapat perintah atau penugasan atau kuasa dari nasabah untuk melakukan transaksi atas kepentingan dari nasabah.

c. Bank meragukan kebenaran atas informasi yang diberikan nasabah, penerima kuasa, dan atau penerima manfaat (Beneficial Owner);

d. Terdapat transaksi keuangan yang dinilai tidak wajar terkait dengan pencucuian uang dan atau pendanaan terorisme.

Peraturan mengenai customer due dilligence (CDD) kembali dilakukan pembaharuan dan penyempurnaan dengan dikeluarkannya Peraturan Otoritas Jasa Keuangan Nomor 12/POJK.01/2017 tentang Penerapan Program Anti Pencucian Uang dan Pencegahan Pendanaan Terorisme di Sektor Jasa Keuangan. Disebutkan dalam POJK ini pengertian dari prinsip CDD adalah uji tuntas nasabah yakni kegiatan berupa identifikasi, verifikasi, serta kegiatan pemantauan yang dilakukan oleh penyedia jasa keuangan (PJK) guna memastikan transaksi nasabah tersebut sesuai dengan profil, karakterisktik, dan/atau pola transaksi dari calon nasabah, atau WIC (walk ini customer). Dalam penjelasannya WIC adalah pihak yang

\footnotetext{
${ }^{14}$ Satrio Sakti Nugroho, 'Implemetasi Customer Due Dilligence Dan Enhanced due dilligence dalam mencegah tindak pidana pencucian uang’ (2014) 3UNNES Law Journal.[49 dan 53].
} 
menggunakan jasa PJK namun tidak memiliki rekening pada PJK, tidak termasuk pihak yang mendapatkan perintah atau penugasan dari nasabah untuk melakukan transaksi atas kepentingan dari nasabah.

Sedikit berbeda dengan peraturan PBI 14/27/PBI/2012, dalam POJK ini penyedia jasa keuangan diwajibkan melakukan prosedur CDD sesuai ketentuan Pasal 15 Peraturan Otoritas Jasa Keuangan Nomor 12/POJK.01/2017, pada saat:

a. Melakukan hubungan usaha dengan calon nasabah;

b. Terdapat transaksi keuangan dengan mata uang rupiah dan/atau mata uang asing yang nilainya paling sedikit atau setara dengan Rp100.000.000 (seratus juta rupiah), termasuk transaksi yang dilakukan dalam satu kali transaksi atau dilakukan dalam beberapa kali transaksi yang patut untuk diduga saling terkait.

c. Terdapat transaksi transfer dana sebagaimana yang dimaksud dalam peraturan OJK ini;

d. Terdapat indikasi keuangan mencurigakan yang terkait dengan pencucian uang dan atau pendanaan terorisme, dilakukan prosedur CDD tanpa memperhatikan adanya pengecualian atau batasan nilai transaksi sebagaimana diatur dalam POJK ini; atau

e. Penyedia jasa keuangan meragukan atas kebenaran dari informasi yang diberikan oleh baik itu calon nasabah, nasabah, penerima kuasa, dan atau pemilik manfaat (Beneficial Owner).

Dijelaskan pada POJK Nomor 12/POJK.01/2017, identifikasi terhadap calon nasabah untuk mengetahui profil calon nasabah dilakukan melalui permintaan data serta informasi yang sekurang-kurangnya meliputi:

1. Identitas yang memuat nama lengkap termasuk nama alias jika ada, tempat dan tanggal lahir, jenis kelamin nomor dokumen identitas, alamat tempat tinggal sesuai dokumen identitas dan alamat tempat tinggal lain jika ada, kewarganegaraan, pekerjaan alamt dan nomor tempat kerja jika ada, dan status perkawinan;

2. Identitas pemilik manfaat (beneficial owner) jika ada;

3. Sumber dana

4. Penghasilan rata-rata per tahun;

5. Maksud dan tujuan hubungan usaha atau transaksi yang akan dilakukan oleh calon nasabah.

Berdarkan POJK di atas dijelaskan bahwa kesemua informasi tersebut wajib didukung dengan dokumen identitas calon nasabah dan spesimen tanda tangan. Penyedia jasa keuangan berkewajiban untuk melakukan verifikasi terhadap informasi dan dokumen pendukung dari calon nasabah tersebut, berdasarkan 
dokumen dan/atau sumber informasi lain yang dapat dipercaya dan independen, serta memastikan bahwa data yang diberikan oleh nasabah tersebut adalah data yang up date atau terkini. Verifikasi tersebut wajib didasarkan pada risiko tindak kejahatan pencucian uang dan atau pendanaan terorisme yang telah di identifikasi berdasarkan penialain risiko yang dilakukan oleh penyedia jasa keuangan, dan wajib untuk melaksanakan serta memenuhi ketentuan yang ada dalam POJK tersebut. Apabila terdapat keraguan data dari penyedia jasa keuangan terhadap kebenaran dokumen calon nasabah, maka penyedia jasa keuangan dapat melakukan wawancara dengan calon nasabah.

Adapun ketentuan dalam POJK Nomor 12/POJK.01/2017, perluasan tentang tindakan secara mendalam setelah dilakukannya prosedur CDD oleh penyedia jasa keuangan terhadap calon nasabah, nasabah, atau WIC, disebut dengan Uji Tuntas Lanjut atau Enhanced Due Dilligence (EDD). EDD tersebut dilakukan secara berkala oleh penyedia jasa keuangan pada pengguna jasa yang tergolong berisiko tinggi atau orang yang dalam kategori politically exposed person (PEP) atau orang yang popular secara politis, terhadap kemungkinan pencucian uang dan pendanaan terorismeterhadap kemungkinan pencucian uang dan pendanaan terorisme.

Sanksi yang akan diberikan pada penyedia jasa keuangan apabila melakukan pelanggaran terhadap ketentuan penerapan prinsip customer due dilligence (CDD), dalam POJK Nomor 12/POJK.01/2017 dijelaskan pada Pasal 66, akan dikenakan sanksi administrasi berupa:

a. Pringatan tertulis

b. Denda dalam bentuk kewajiban membayar sejumlah uang

c. Penurunan dalam penilaian tingkat kesehatan,

d. Pembatasan kegiatan usaha

e. Pembekuan kegiatan usaha tertentu

f. Pemberhentian pengurus bank dan selanjutnya menunjuk dan mengangkat pengganti sementara sampai RUPS atau rapat anggota koperasi mengangkat pengganti yang tetap dengan persetujuan OJK; dan/atau

g. Pencantuman anggota direksi dan anggota dewan komisaris, pegawai penyedia jasa keuangan, pemegang saham dalam daftar orang tercela di sektor keuangan. 


\section{Praktik Pencucian Uang Dalam Sektor Perbankan}

Pencucian uang dalam artian sederhananya adalah "bersih-bersih" terhadap uang atau harta si pelaku agar tidak diketahui oleh pihak lain bahwa uang tersebut sebenarnya berasal dari hasil tindak pidana atau kejahatan. Dengan kemajuan teknologi dan kompleksitas sistem keuangan, serta semakin beragamnya modus operandi pelaku pencucian uang menjadikan praktik tindak kejahatan pencucian uang dapat dilakukan dengan cara lainnya. ${ }^{15}$ Definisi pencucian uang dijelaskan dalam Pasal 1 angka 1 undang-undang Nomor 25 Tahun 2003 tentang Perubahan Atas Undang-undang Nomor 15 Tahun 2002 tentang Tindak Pidana Pencucian Uang. Dijelaskan bajwa pencucian uang adalah suatu perbuatan menempatkan, mentransfer, membayarkan, membelanjakan, menghibahkan, menyumbangkan, menitipkan, membawa ke luar negeri, menukarkan, atau perbuatan lainnya atas harta kekayaan yang diketahuinya atau patut diduga merupakan hasil tindak pidana dengan maksud untuk menyembunyikan, atau menyamarkan asal usul harta kekayaan sehingga seolah-olah menjadi harta kekayaan yang sah.

Undang-Undang Nomor 23 Tahun 2003 ini kemudian dicabut, diganti dengan dikeluarkannya Undang-Undang Nomor 8 Tahun 2010 tentang Pencegahan dan Pemberantasan Tindak Pidana Pencucian Uang. Sedangkan menurut Pasal 1 angka 1 Undang-Undang Nomor 8 Tahun 2010 yang dimaksud dengan pencucian uang adalah segala perbuatan yang memenuhi unsur-unsur pidana sesuai ketentuan dalam Undang-Undang Nomor 8 Tahun 2010.

Undang-Undang PP TPPU telah mewajibkan bank pada setiap calon nasabahnya baik perorangan maupun korporasi yang akan menyimpan dananya di bank untuk menyampaikan identitasnya secara lengkap dan benar, serta dibuktikan dengan dokumen sebagai pendukungnya. Namun demikian, ketentuan ini tetap saja memerlukan kemampuan pegawai bank untuk lebih jeli mengetahui identitas calon nasabah yang sesungguhnya. Karena ada kemungkinan nasabah melakukan duplikasi nama atau pemalsuan nama, serta pemalsuan dokumen

15 I Ketut Sukawati Lanang Putra Perbawa, 'Tindak Pidana Pencucian uang Dalam Sistem Perbankan Indonesia' (2015) 5 Jurnal Advokasi.[43]. 
lainnya dan cara-cara yang lain untuk mengelabui pegawai bank atau perusahaan jasa lainnya. ${ }^{16}$

Dijelaskan pada Pasal 18 ayat (1) yakni kewajiban lembaga pengawas dan pengatur untuk menetapkan ketentuan prinsip mengenali pengguna jasa. Diterangkan lebih lanjut pada ayat (2) bahwa adanya kewajiban untuk menerapkan prinsip mengenali pengguna jasa yang ditetapkan oleh setiap lembaga pengawas dan pengatur. Dalam penjelasan ayat (2) yang dimaksud "menerapkan prinsip mengenali pengguna jasa" adalah customer due dilligence (CDD) dan enhanced due dilligence $(E D D)$ sebagaimana yang dimaksud dalam rekomendasi 5 FATF. Dalam penerapannya, prinsip mengenali nasabah harus memuat sekurang-kurangnya mengenai identifikasi, verifikasi dan pemantauan atas transaksi pengguna jasa. ${ }^{17}$

Adapun kewajiban menerapkan prinsip mengenali pengguna jasa, dijelaskan dalam Undang-Undang PP TPPU ini pada Pasal 18 ayat (3), dilakukan pada saat:

a. Melakukan hubungan usaha dengan pengguna jasa;

b. Terdapat transaksi keuangan dengan mata uang rupiah dan atau asing yang nilainya paling sedikit atau setara dengan Rp100.000.000 (seratus juta rupiah);

c. Terdapat transaksi keuangan yang mencurigakan terkait dengan tindak pidana pencucian uang;

d. Pihak pelapor meragukan kebenaran informasi yang dilaporkan oleh pengguna jasa.

Ketika bank sebagai penyedia jasa keuangan saat menerapkan prinsip kehatihatian berkaitan dengan pencegahan tindak pencucian uang yakni penerapan prinsip mengenal nasabah, yang disebut dalam UU PP TPPU adalah prinsip mengenali pengguna jasa namun pengguna jasa menolak untuk mematuhinya prinsip tersebut, atau bank meragukan kebenaran informasi yang disampaikan oleh pengguna jasa. Maka menurut Pasal 22 Undang-Undang PP TPPU, bank sebagai penyedia jasa keuangan untuk memutuskan hubungan usaha dengan pengguna jasa yang dimaksud. Ketika bank memutuskan hunungan usaha tersebut, kemudian bank wajib untuk melaporkannya kepada PPATK mengenai tindakan pemutusan

\footnotetext{
${ }^{16}$ Andrian Sutedi, Hukum Perbankan,Suatu Tujuan Pencucian Uang, Merger, Likuidasi, Dan Kepailitan (Sinar Grafika 2010).[76].

17 Dewi Anggraeni Pujianti, 'Penerapan Prinsip Mengenal Nasabah (Know Your Customer Principles) Dalam Mencegah Tindak Pidana Pencucian Uang' (Universitas Indonesia 2011)..[63].
} 
hubungan usaha tersebut sebagai transaksi keuangan mencurigakan. Menurut Pasal 1 angka 5 Undang-Undang PP TPPU dijelaskan bahwa transaksi keuangan mencurigakan adalah :

a. Transaksi keuangan yang menyimpang dari profil, karakterisktik, atau kebiasaan pola transaksi dari pengguna jasa yang bersangkutan;

b. Transaksi keuangan oleh pengguna jasa yang patut diduga dilakukan dengan tujuan untuk menghindari pelaporan transaksi yang bersangkutan yang wajib dilakukan oleh pihak pelapor sesuai dengan ketentuan undang-undang ini;

c. Transaksi keuangan yang dilakukan atau batal dilakukan dengan menggunakan harta kekayaan yang diduga berasal dari hasil tindak pidana; atau

d. Transaksi keuangan yang diminta oleh PPATK untuk dilaporkan oleh pihak pelapor karena melibatkan harta kekayaan yang diduga berasal dari hasil tindak pidana.

Selain dijelaskan pada Pasal 5, transaksi keuangan mencurigakan juga dijelaskan pada penjelasan Pasal 23 ayat (1) huruf a, tentang cirri-ciri umum dari tranksaksi keuangan mencurigakan antara lain:

1. Tidak memiliki tujuan ekonomis dan bisnis yang jelas;

2. Menggunakan uang tunai dalam jumlah yang relatif besar dan/atau dilakukan secara berulang-ulang diluar kewajaran; atau

3. Aktivitas transaksi nasabah di luar kabiasaan dan kewajaran.

Apabila telah memenuhi kriteria tersebut, penyedia jasa keuangan wajib melakukan pelaporan kepada PPATK yang meliputi:

a. Transaksi keuangan mencurigakan;

b. Transaksi keuangan tunai dalam jumlah paling sedikit Rp500.000.000 (lima ratus juta rupiah) atau dengan mata uang asing yang nilanya setara, yang dilakukan dalam satu kali transaksi maupun beberapa kali transaksi dalam satu hari kerja;

c. Transaksi keuangan transfer dana dari dan ke luar negeri.

Dijelaskan dalam Pasal 25 ayat (4) Undang-Undang PP TPPU bahwa, apabila penyedia jasa keuangan tidak menyampaikan ketiga jenis laporan di atas kepada PPATK, maka akan ada sanksi administratif yang akan dikenakan berupa peringatan, teguran tertulis, pengumuman pada pubik perihal tindakan atau sanksi. Namun kewajiban pelaporan dikecualikan untuk jenis transaksi yang dilakukan oleh penyedia jasa keuangan dengan pemerintah dan bank sentral, transaksi untuk 
pembayaran gaji atau pensiun, dan transaksi lain yang ditetapkan oleh kepala PPATK atau atas permintaan penyedia jasa keuangan yang disetujui oleh PPATK, seperti yang dijelaskan dalam Pasal 23 ayat (4) Undang-Undang PPTPPU.

\section{Implikasi Prinsip Mengenal Nasabah Terhadap Pemberantasan Tindak Pidana Pencucian Uang}

Sebagai salah satu lembaga penyedia jasa keuangan yang berperan penting bagi perekonomian negara, bank dalam setiap kebijakannya akan memberikan pengaruh penting terhadap kehidupan perekonomian di sutu negara. Hal tersebut menunjukan bahwa posisi bank yang sangat riskan terlebih apabila bank dijadikan media untuk suatu kegiatan tindak pidana oleh pihak-pihak yang tidak bertanggungjawab. ${ }^{18}$ Dalam melaksanakan kegiatannya, bank memiliki beberapa prinsip utama yang wajib di implemetasikan, salah satu prinsip utama tersebut adalah prinsip mengenal nasabah. Prinsip mengenal nasabah merupakan realisasi dari prinsip kehati-hatian dalam sektor perbankan.

Arti penting penerapan prinsip tersebut ialah sebagai pilar pertama ketika calon nasabah akan berhubungan dengan bank, maka bank diwajibkan untuk melakukan penelitian dan pemeriksaan mendalam mengenai identitas, maksud, dan tujuan serta kegiatan transaksi dari nasabah. ${ }^{19}$ Dalam hal kebijakan penerimaan nasabah dan identifikasi nasabah sebagai penerapan prinsip mengenal nasabah oleh bank, telah diatur prosedurnya dalam Peraturan Bank Indonesia (PBI), Peraturan Otoritas Jasa Keuangan dan Undang-Undang PP TPPU dengan penyempurnaan ketentuan sedemikian rupa yang terus dilakukan berkaitan dengan pencucian uang. Prinsip mengenal nasabah yang telah diatur dalam Undang-Undang PP TPPU menekankan upaya pencegahan dan pemberantasan praktik pencucian uang. Undang-Undang PP TPPU mewajibkan pada setiap calon nasabah untuk menyampaikan identitasnya secara lengkap dan benar serta dapat dibuktikan dengan dokumen pendukung.

18 ibid.[74].

${ }^{19}$ Suryadi M. Sahara, 'Prinsip Kehati-Hatian Dan Prinsip Mengenal Nasabah Sebagai Upaya Perbankan Mencegah Tindak Pidana Pencucian Uang' (2018) 6 Jurnal Lex Et Societatis.[103]. 
Telah dijelaskan bahwa jika bank melakukan pelanggaran atas kewajibannya menerapkan prinsip mengenal nasabah dan lalai dalam kewajiban melakukan pelaporan atas adanya transaksi yang mencurigakan, maka bank akan dikenakan sanksi administratif sesuai dengan ketentuan dalam peraturan perundang-undangan.

Dapat dikatakan bahwa tindak pidana pencucian uang bisa terjadi apabila bank mengabaikan dan tidak menerapkan prinsip mengenal nasabah yang selanjutnya diubah dengan customer due dilligence (CDD) dan diperluas dengan menerapkan enhanced due dilligence (EDD). Hal tersebut telah diwajibkaan oleh peraturan perundangundangan untuk dilakukan secara berkala terhadap nasabah berisiko tinggi. Ketika bank tidak menerapkan prinsip tersebut secara komprehensif dan ketat, melakukan membiaran pada nasabah penyimpan dana dengan tidak adanya pengawasan yang ketat akibat tidak diterapkannya prinsip mengenal nasabah yang jelas, pasti dan tegas, atau yang berimplikasi terhadap pencucian uang, maka bank dalam hal ini dapat dianggap melakukan tindak pidana pencucian uang, karena kecil kemungkinan bank tidak mengetahui setiap profil dan karakteristik transaksi dari tiap-tiap nasabahnya.

Jika bank dengan serius menerapkan prinsip mengenal nasabah CDD dan EDD tanpa terkecuali sesuai prosedur dalam peraturan perundang-undangan yang sedemikian rupa, maka bank telah melaksanakan upaya pencegahan tindak pidana pencucian uang yang telah diamanatkan oleh peraturan perundang-undangan. Dengan begitu bank dapat terhindar menjadi sarana tindak pidana pencucian uang oleh pihak yang tidak bertanggungjawab. Apabila terdapat nasabah yang lolos dalam menyimpan dana hasil kejahatan suatu tindak pidana, maka patut dipertanyakan pelaksanaan kewajiban penerapan prinsip mengenal nasabah CDD dan EDD oleh bank apakah telah sesuai prosedur yang diatur atau bank. Dari uraian di atas maka dalam hal ini, prinsip mengenal nasabah patut sekali menjadi tolak ukur dalam kejahatan tindak pidana pencucian uang yang dilakukan bank, mengingat akan pentingnya prinsip mengenal nasabah dalam upaya pencegahan tindak pidana pencucian uang yang menjadikan bank sebagai media tindak kejahatan tersebut.

Dari penjelasan tersebut di atas, dalam kaitanya dengan kasus Fuad Amin, bank dapat dikatakan melakukan tindak pencucian uang karena bank tidak melaksanakan 
prinsip kehati-hatian yang berkaitan dengan pencegahan tindak pidana pencucian uang yakni prinsip mengenal nasabah yang telah mengalami perkembangan dengan adanya customer due diligence (CDD) dan Enhanced Due Diligence (EDD).

Bank selain menerapkan CDD sebagai kewajiban utama, seharusnya juga menerapkan enhanced due diligence (EDD) pada nasabah berisiko tinggi seperti Fuad Amin, diketahui bahwa Fuad Amin adalah seseorang yang popular secara politis (Politically Exposed Person). Dijelaskan dalam penjelasan Pasal 33 huruf a Peraturan Otoritas Jasa Keuangan Nomor 24/POJK.04/2014 tentang Prinsip Mengenal Nasabah Oleh Penyedia Jasa Keuangan Di Sektor pasar Modal, bahwa contoh dari politically exposed person (PEP) antara lain adalah anggota legislatif baik di tingkat pusat maupun tingkat daerah serta siapapun orang yang karena posisinya yang tinggi di masyarakat, dan pengaruh yang signifikan. Setelah diketahui tindakan bank ketika tidak menjalankan kewajibannya untuk menerapkan prinsip kehati-hatian berkaitan dengan pencegahan tindak pidana pencucian uang yakni prinsip mengenal nasabah, CDD dan EDD, dapat dikatakan bank melakukan tidak pencucian uang.

\section{Pertanggungjawaban Bank Yang Tidak Melaksanakan Prinsip Kehati-Hatian}

\section{Bank Berkiatan dengan Upaya Pencegahan Tindak Pidana Pencucian Uang} Dalam Undang-Undang TPPU dan Undang-Undang Perbankan

Apabila melihat dalam Undang-Undang Tindak Pidana Pencucian Uang, pada ketentuan Pasal 5 Udang-Undang PP TPPU, pada ayat (1) menyebutkan bahwa setiap orang yang menerima atau menguasai penempatan, pentransferan, pembayaran, hibah, sumbangan, penitipan, penukaran, atau menggunakan harta kekayaan yang diketahuinya atau patut diduganya merupakan hasil tindak pidana sebagaimana dimaksud dalam Pasal 2 ayat (1) dipidana dengan pidana penjara paling lama 5 (lima) tahun dan denda paling banyak Rp 1.000.000.000 (satu milyar rupiah). Dalam Undang-Undang PP TPPU dijelaskan pada Pasal 1 angka 9 bahwa yang dimaksud setiap orang adalah orang perseorangan atau korporasi. Dalam bahasan ini korporasi yang dimaksud adalah bank sebagai penyedia jasa keuangan. Namun hal ini tidak berlaku atau dikecualikan bagi pihak pelapor yang melaksanakan 
kewajiban pelaporan sebagaimana diatur dalam Undang-Undang PP TPPU, hal ini dijelaskan pada Pasal 5 ayat (2). Pihak pelapor sebagaimana disebutkan Pasal 17 yang meliputi penyedia jasa keuangan, salah satunya adalah bank.

Apabila bank tidak melaksanakan kewajiban pelaporan, dijelaskan pada Pasal 6 ayat (1) Undang-Undang PP TPPU bahwa dalam hal tindak pidana pencucian uang sebagaimana dimaksud dalam Pasal 3, Pasal 4, dan Pasal 5 dilakukan oleh korporasi, pidana dijatuhkan terhadap korporasi dan/atau personil pengendali korporasi. Selanjutnya Pasal 6 ayat (2) menjelaskan bahwa pidana dijatuhkan terhadap korporasi apabila tindak pidana pencucian uang:

a. Dilakukan atau diperintahkan oleh personil pengendali korporasi;

b. Dilakukan dalam rangka pemenuhan maksud dan tujuan korporasi;

c. Dilakukan sesuai dengan tugas dan fungsi pelaku atau pemberi perintah; dan

d. Dilakukan dengan maksud memberikan manfaat bagi korporasi.

Ke-empat syarat tersebut bersifat alternatif, jadi ketika salah satu syarat tersebut terpenuhi, maka korporasi dapat dijatuhkan pidana atas pencucian uang.

Dijelaskan pada Pasal 7 UU PP TPPU pidana pokok yang dijatuhkan terhadap korporasi adalah pidana dengda paling banyak Rp100.000.000.000 (seratus milyar rupiah). Selain pidana pokok, terhadap korporasi juga dapat dijatuhkan pidana tambahan berupa :

a. Pengumuman putusan hakim;

b. Pembekuan sebagian atau seluruh kegiatan usaha korporasi;

c. Pencabutan isin usaha;

d. Pembubaran dan/atau pelanggaran korporasi;

e. Perampasan asset korporasi untuk Negara; dan/atau

f. Pengambilalihan korporasi oleh Negara.

Melihat pada Undang-Undang Perbankan, Perbankan telah mengatur perbuatan-perbuatan yang dilarang untuk dilakukan oleh bank sebagai penyedia jasa keuangan maupun individu bagian dari kegiatan pengelolaan bank pada kegiatan operasionalnya. Undang-Undang Perbankan mengatur tentang perbuatanperbuatan yang dikategorikan sebagai perbuatan pidana baik kejahatan maupun pelanggaran. Hal tersebut dapat dilihat pada rumusan Pasal 51 Undang-Undang Perbankan. Undang-Undang Perbankan menetapkan bermcam-macam tindak pidana yang diatur mulai dari Pasal 46 sampai dengan Pasal 50 A. Tindak pidana 
tersebut digolongkan ke dalam empat macam, yakni :

a. Tindak pidana berkaitan dengan perizinan, dijelaskan pada Pasal 46;

b. Tindak pidana yang berkaitan dengan rahasia bank, dijelaskan Pada Pasal 47, dan Pasal 47 A;

c. Tindak pidana yang berkaitan dengan pengawasan dan pembinaan, dijelaskan pada Pasal 48;

d. Tindak pidana yang berkaitan dengan usaha bank, dijelaskan pada Pasal 49, Pasal 50, dan Pasal 50 A.

Bank sebagai korporasi dapat secara langsung melakukan tindak pidana melalui individu, pihak, atau organ dalam bank. Bank mau bertanggungjawab atas kelalaian apabila memenuhi unsur-unsur:

a. Adanya suatu perbuatan yang dilakukan oleh bank yang bertentangan dengan ketentuan dalam Undang-Undang Perbankan, dan perbuatan tersebut tidak terdapat unsur permbenar;

b. Perbuatan yang dilakukan oleh bank menimbulkan kerugian bagi nasabah penyimpan;

c. Adanya hubungan kausal antara perbuatan melanggar hukum yang dilakukan oleh bank dengan kerugian yang diderita oleh nasabah penyimpan. ${ }^{20}$

Dari ketiga unsur tersebut, biasanya dilakukan oleh pegawai atau karyawan bank. Berdasarkan Pasal 1603 KUH Perdata, mengatur bahwa setiap karyawan mempunyai tanggungjawab untuk melakukan pekerjaan sebaik-baiknya dengan memperhatikan kepatutan. ${ }^{21}$

Diketahui bahwa Undang-Undang Perbankan masih menetapkan subjek tindak pidana perbankan terbatas pada perseorangan, yakni terhadap pegawai, pengurus atau pejabat bank. Perihal pertanggungjawaban bank, melihat pada ketentuan Undang-Undang Perbankan Pasal 46 ayat (2) yang menyebutkan bahwa penuntutan dilakukan terhadap pihak yang memberi perintah untuk melakukan perbuatan itu atau yang bertindak sebagai pimpinan dalam perbuatan itu, atau terhadap keduanya-duanya. ${ }^{22}$ Pasal inilah yang menunjukan bahwa Undang-

${ }^{20}$ Rani Sri Agustina, Rahasia Bank (Keni Media 2017).[3].

21 ibid.

${ }^{22}$ Bambang Purwogandi Dito Ari Legowo dan Sri Endah Wahyuningsih, 'Kebijakan Hukum Pidana Pertanggungjawaban Korporasi Terhadap Tindak Pidana Perbankan Dalam Sistem Hukum di Indonesia' (2017) 12 Jurnal Hukum Khaira Ummah.[531]. 
Undang Perbankan menggunakan model pertanggungjawaban vicarious liability sebagai sistem pertanggunjawaban pidana bank. Pasal tersebut telah mengakui bahwa korporasi dapat melakukan tindak pidana sebagaimana yang dimaskud dalam ayat (1), namun yang bertanggung-jawab bukan korporasinya melainkan mereka yang memberi perintah melakukan perbuatan tersebut, atau yang bertindak sebagai pimpinan dalam perbuatan itu, atau terhadap keduanya.

Dengan begitu dapat diketahui bahwa Undang-Undang Perbankan masih mengikuti pemikiran bahwa yang dapat melakukan tindak pidana hanyalah manusia alamiah (naturlijk persoon). Dilihat dari pasal ketentuan pidana dan sanksi admnistratif yang menjelaskan bahwa pertanggungjawaban pidana di bebankan pada pihak yang bertindak sebagai pimpinan korporasi. Pertanggungjawaban ini diartikan bahwa majikan adalah penanggungjawab utama dari perbuatan para karyawan, juga bisa didasarkan pada delegation principle, bahwa a quality mind dari karyawan dapat dihubungkan ke majikan apabila ada pendelegasian kewenangan dan kewajiban yang relevan menurut Undang-Undang.

Melihat dalam ketentuan Pasal 49 Undang-Undang Perbankan yang menjelaskan anggota dewan komisaris, direksi, atau pegawai bank, yang dengan sengaja membuat catatan palsu, menghilangkan atau tidak memasukan atau menyebabkan tidak dilakukannya pencataan, mengubah, mengaburkan, menyembunyikan, catatan dalam pembukuan, dalam laporan, atau dokumen laporan transaksi atau rekening suatu bank, daincam dengan pidana penjara sekurangkurangnya 5 tahun dan paling lama 15 tahun serta denda sekurang-kurangnya Rp10.000.000.000 (sepuluh milyar rupiah) dan paling banyak Rp200.000.000.000 (dua ratur milyar rupiah). Apabila setelah dilakukan penyelidikan dan penyidikan, dan terbukti pegawai bank yang bersangkutan dengan kasus Fuad Amin telah memalsukan dokumen-dokumen dari Fuad Amin untuk ikut membantu dalam tindak pidana pencucian uang, maka Pasal 49 Undang-Undang Perbankan tersebut sepatutnya untuk diperhatikan. 


\section{Kesimpulan}

Setiap bank oleh peraturan perundang-undangan diwajibkan untuk bertindak hati-hati dan menerapkan prinsip-prinsip utama dalam perbankan, khususnya prinsip kehati-hatian serta prinsip mengenal nasabah CDD dan EDD sebagai langkah pertama upaya pemberantasan tindak pidana pencucian uang di sektor perbankan. Penerapan prinsip tersebut berdasarkan pemantauan profil dan kegiatan transaksi nasabah secara berkala untuk menghindari kegiatan pencucian uang. Tidak sepatutnya bank melakukan pembiaran apabila terdapat transaksi yang mencurigakan dari nasabahnya karena bank memiliki kewajiban untuk melakukan pelaporan pada PPATK apabila terdapat transaksi yang mencurigakan dan adanya ancaman sanksi pada bank apabila melakukan pelanggaran seperti yang telah dijelaskan sebelumnya.

Pada kasus Fuad Amin yang penulis dengan melihat dari sisi bank yang dijadikan Fuad Amin sebagai sarana untuk menempatkan uang hasil korupsinya dalam upaya menyembunyikan asal uang atau harta yang di dapatnya dengan melakukan pemecahan penempatan ke beberapa bank, atas nama dirinya namun menggunakan identitas yang berbeda-beda. Dalam hal ini tidak mungkin bank tidak mengetahui siapa sebenarnya sosok Fuad Amin sebagai nasabahnya, dan melakukan pembiaran pada Fuad Amin untuk meletakan hartanya di bank dengan identitas yang berbeda-beda.

Hal tersebut mengisyatakan bahwa bank-bank tersebut tidak melakukan penerapan prinsip kehati-hatian dan prinsip mengenal nasabah serta mengabaikan proses CDD dan EDD. Prinsip tersebut semestinya dilakukan secara ketat, teliti serta prosedural sebagaimana yang menjadi kewajiban bank sesuai dengan peraturan perundang-undangan. Maka bank dapat dianggap melakukan tindak pidana pencucian dan dapat dikatan pula bahwa prinsip mengenal nasabah patut menjadi tolak ukur bank melakukan tindak pidana dalam kejahatan tindak pidana pencucian uang.

Pertanggungjawaban bank dalam tindak pencucian uang, melihat ketentuan Undang-Undang Perbankan, Pasal 46 ayat (2) disebutkan bahwa penuntutan dilakukan terhadap mereka yang memberi perintah untuk melakukan perbuatan 
tersebut, atau yang bertindak sebagai pimpinan dalam perbuatan tersebut, atau terhadap keduanya. Dalam kasus Fuad Amin, pertanggungjawaban pidana dapat dikenakan pada kepala cabang sebagai directing mind dari kantor cabang, bank dapat dimintai pertanggungjawaban pidana jika memenuhi salah satu unsur kategori korporasi dapat dimintai pertanggungjawaban dalam peraturan perundangundangan yang mengatur mengenai pemidanaan korporasi, dalam hal ini UndangUndang PP TPPU dan Undang-Undang Perbankan.

\section{Daftar Bacaan}

\section{Buku}

Andrian Sutedi, Hukum Perbankan,Suatu Tujuan Pencucian Uang, Merger, Likuidasi, Dan Kepailitan (Sinar Grafika 2010).

Arief Amrullah, Tindak Pidana Pencucian uang (Money Laundering) (Bayumedia Publishing 2004).

Didik Endro Purwoleksono, Hukum Pidana (Airlangga University Press Surabaya 2014).

Nidyo Pramono, Bunga Rampai Hukum Bisnis Aktual (Cintra Aditya 2006).

Rani Sri Agustina, Rahasia Bank (Keni Media 2017).

Ruslan Renggong, Hukum Pidana Khusus (Memahami Delik-delik di Luar KUHP) (Kencana 2016).

Sentosa Sembiring, Hukum Perbankan Edisi Revisi (Mandar Maju 2012).

Tri Sadini P.Usanti dan Abd.Shomad, Hukum Perbankan (Kencana 2016).

Try Widyono, Aspek Hukum Operasional Transaksi Produk Perbankan di Indonesia. (Ghia Indonesia Bogor 2006).

\section{Jurnal}

Bambang Purwogandi Dito Ari Legowo dan Sri Endah Wahyuningsih, 'Kebijakan Hukum Pidana Pertanggungjawaban Korporasi Terhadap Tindak Pidana Perbankan Dalam Sistem Hukum di Indonesia' (2017) 12 Khaira Ummah.

Detisa Monica Podung, 'Kredit Macet dan Penerapan Prinsip Kehati-Hatian Dalam 
Perbankan' ( 2016) 5 Lex Crimen.

I Ketut Sukawati Lanang Putra Perbawa, 'Tindak Pidana Pencucian uang Dalam Sistem Perbankan Indonesia' (2015) 5 Advokasi.

Lukmanul Hakim dan Eka Travilta Oktaria, 'Prinsip Kehati-hatian Pada Lembaga Perbankan Dalam Pemberian Kredit' (2018) 9 Keadilan Progresif.

Satrio Sakti Nugroho, 'Implemetasi Customer Due Dilligence Dan Enhanced due dilligence dalam mencegah tindak pidana pencucian uang' (2014) 3UNNES Law Journal.

Suryadi M. Sahara, 'Prinsip Kehati-Hatian Dan Prinsip Mengenal Nasabah Sebagai Upaya Perbankan Mencegah Tindak Pidana Pencucian Uang’ (2018) 6 Lex Et Societatis.

\section{Perundang-undangan}

Undang-Undang Nomor 8 Tahun 2010 Tentang Pencegahan dan Pemberantasan Tindak Pidana Pencucian Uang.

Undang-Undang Nomor 7 tahun 1992 jo Undang-Undang Nomor 10 Tahun 2010 Tentang Perbankan.

Putusan mahkamah Agung, nomor 980 K/Pid.Sus/2016 tahun 2016.

PBI Nomor 11/28/PBI/2009 tentang Penerapan Program Anti Pencucian Uang dan Pencegahan Pendanaan Terorisme Bagi Bank Umum.

PBI Nomor 14/27/PBI/2012, tentang Penerapan Program Anti Pencucian Uang dan Pencegahan Pendanaan Terorisme Bagi Bank Umum.

Peraturan Otoritas Jasa Keuangan Nomor 12/POJK.01/2017 tentang Penerapan Program Anti Pencucian Uang dan Pencegahan Pendanaan Terorisme di Sektor Jasa Keuangan.

\section{Peraturan Teknis Lainnya}

Pusat Pelaporan dan Analisis Transaksi Keuangan (PPATK) Modul E-Learning 1, "Pengenalan Anti Pencucian Uang dan Pendanaan Terorisme", h. $3<$ http:// elearning.ppatk.go.id/pluginfile.php/269/mod_page/content $/ 5 / \mathrm{Mod} \% 20$ 1\%20-\%20Bag\%202\%20-\%20Tipologi\%20Pencucian\%20Uang.pdf> accessed 13 November 2019. 
1828 Istiqomah: Pertanggungjawaban Bank Dalam

--halaman ini sengaja dibiarkan kosong-- 